\title{
Pattern of Desertification in Yobe State of Nigeria
}

\author{
${ }^{1}$ Amadi D. C. A. ${ }^{1}$ Maiguru Abel; ${ }^{1}$ Zaku Sabo and ${ }^{2}$ YakubuTor-Agbidye. \\ ${ }^{I}$ Department of Forestry and Wildlife Management, Federal University Wukari Taraba State, Nigeria \\ ${ }^{2}$ Department of Animal Production and Health, Federal University, Wukari,Taraba state Nigeria.
}

\begin{abstract}
In this paper, the pattern of desertification in Yobe State of Nigeria was investigated. A multistage stratified sampling technique was used to select the eighteen development Areas for study. Data on the causes, damages / influence, and remedies for desertification were collected through the use of questionnaires and aerial photographs obtained from the North East Arid Zone Development Programme (NEAZDP) for the 1990s and 2000s. Data analysis employed the use of descriptive statistics and interpretation of aerial photographs. The photo interpretations were used to establish the presence of sand dunes, bare grounds, depletion of water bodies and vegetation cover. These interpretations were further validated at the Regional Centre for Remote Sensing in Jos, Plateau state of Nigeria. The study showed the expanding desert as one of the severe environmental problems. A combination of climatic factors, increase in population and livestock pressure on the land and vegetation has been identified as the chief causes of desertification. Environmental degradation have been significant particularly in the case of reduction in water body, depletion of vegetation cover, shifting sand dunes, increasing bare grounds and loss of biodiversity. The study suggests some remedial and corrective antidesertification measures such as the incorporation of indigenous desert control knowledge into government environmental conservation Programmes as well as massive and sustained tree planting exercise with recommended and adaptable tree species.
\end{abstract}

Key Words: Desertification, Development Areas, Aerial Photographs, environmental Degradation.

\section{Introduction}

Mans relationship with the environment is interwoven. Indeed, the environment has always been the centre of man's concern and study. Man-environmental relationship involves reaction by man to his environment which varies over space and time (Olofin, 1989, Mikesell, 1974) described man-nature relationship as a two way affair. Man affects his environment in terms of human activities, thereby creating a state of dynamic equilibrium that continues to adjust and readjust in space with time.

The most common method used by local people in coping with environmental changes caused by desertification is movement. The pastoral nomads are victims as droughts have decimated their herds. Movements are directed to the cities and some of the unaffected agricultural regions. People will go anywhere if there is hope of earnings. Initially, movement may involve only adult males but as dry conditions continue whole families may move away. According to Mortimore (1987), increase in dry conditions has a positive effect on the number of families moving away. The drought may liquidate most of their resources and thus leave them with no visible means of subsistence. The 1984 drought in the Horn of Africa left as many as two thirds of the population as temporary refugees in towns and cities such as Port Sudan (Hjort, 1990).

\section{Methodology}

The multistage stratified sampling technique was used in selecting the eighteen development area in Yobe State of Nigeria. The nature of data collected includes respondents' settlement area, their ages, marital status, educational background, household size, source and types of energy use and their costs, role in tree planting/removal, population change, change in vegetation cover, water body and sand dune accumulation. The main source of data are through questionnaire, satellite images, field observations, and interviews with community and household heads, and some officials of North East Arid Zone Development Programme (NEAZDP).

A total of 1,750 respondents representing 5 percent of the total population in the eighteen development areas were sampled (Table1) Data analysis involved the use of descriptive statistics such as means, frequencies and percentages and the interpretation of the Satellite images to determine the areas occupied by sand dunes, water bodies extent of bare ground and vegetation cover (Plates 1and 2). This is because remote sensing and satellite imagery have been the most recent methods of analyzing environmental change (Whitemore, 1990). 


\section{Causes of Desertification.}

\section{Results.}

All the respondents (5.22\%) comprising of 1,779 households (Table 1). Agreed that the area is facing a serious environmental problem are eagerly waiting for remedial action by the government. The study showed livestock pressure, climatic factors and population pressure as the chief cause of desertification (Table 2).

Hence, desertification is resultant of overgrazing, trampling on the soil which reduces pore space, scanty rainfall and high solar radiation that accelerates evapotranspiration. These have been aggravated by increased human activities such as clear cutting, farming, ranching and urbanization (Julie, Kerr Casper 2007). All the three factors accounted for 85.7 percent of the causes of desertification.

Effects of Desertification

The general effect of desertification is shown in Table 4. Moreover, the three satellite imageries show an increasing area of sand dune coverage for 1978, 1995 and 2002; and declining areas of vegetation cover, water body and bear ground in the Gashua area. Generally, the area with severe environmental change covers between 200,000 and 240,000 square kilometers, amounting to about $26.6 \%$ of its landmass. The area is characterized by scanty rainfall averaging $600 \mathrm{~mm}$ with annual variation. It is also characterized by low number of trees per hectare among which is few fire tolerant plant species. The increasing movement of sand dunes is one of the indicators of desertification, and leads to loss of biodiversity. Wind erosion aggravates the problems by creating sand dunes particularly in Yunusari, Yusufari, Geidam, Nguru and Machina Development Areas.

Even though the area covered by sand dunes decline southwards, no development area of the state has less than 35,000 ha of sand dunes.

Incidence of bare ground is a major indicator of desertification. The areas that show the existence of sand dunes are the same areas that contain extensive bare ground except in Muguram. Sand dunes are infertile and do not encourage the existence of vegetation. They only expose the bare ground. Extensive bare ground areas as found in Machina, Kaska, Yusufari, Yunusari, Kanama areas (Plate 3).

Dry conditions are high in places having sand dunes, bare ground and less vegetation cover. The dry condition favors the formation of sand dunes, drying up of the little water present and giving rise to occurrence of bare ground, in Bulanguwa, Machina, Karasuwa, Yusufari, Yunusari, Kanama and Degeltura Development Areas where the mean decline per annum was about 7,000 ha between 1998 and 2000. (Table 3).

Control of Desertification

Response as to how to control desertification is shown in Table 5. Tree planting is highly needed and recommended using fast growing tree species such as Azadiratchta indica and Jatropha to stabilize and fix sand. Other measures include legislation against tree felling, encouraging use of kerosene stoves, irrigation and discouragement of bush burning.

\section{Summary}

Desertification has resulted in large areas being covered by sand dunes, extensive bare ground, and reduction in water body, vegetation and loss of biodiversity. It is generally observed that area covered by sand dune increased by $10 \%$ between 1978 and 2002 . Vegetation cover reduced by $47 \%$, water body decreased by $16 \%$, while percentage of bare ground increased by $41 \%$ over the same period. This situation urgently need to be addressed since the range of copping strategies pursued by families in drought prone areas may be changing over time (Uyanga, 2002). The need for grass root mobilization and Governments practical commitment to mass tree planting in the area cannot therefore be overemphasized. List of tree species for desertification control is also provided.

\section{Recommendations}

It is therefore recommended that concerted and sustained effort be mobilized by the local population, Local, State and Federal Governments towards mass tree planting in the whole area. This will be sustained by legislation to discourage tree felling and adequate provision of alternative source of energy sources such as kerosene. Botswana is reputed for having developed one of the most efficient drought relief schemes (Silitshena, 1990) and may be copied by Nigeria with caution so as not to disrupt the traditional system of copping with the hazards.

Recommended Interesting anti-desertification plants

The following interesting plant species under their scientific or vernacular names

Are recommended for desertification control:

Azadiratchta india, Amaranthus spp. Amaranth, Annona cherimola cherimoya,

Annona muricata : guanabana, soursop, graviola, Asimina triloba : pawpaw,

Cleome gynandra : African cabbage, cat's whiskers, Dacryodes edulis : safou or

butterfruit, Gmelina arborea, Ipomoea batatas : sweet potato, Irvingia gabonensis : Dika

tree, Jatropha, Moringa oleifera : Moringa, Oxytenanthera abyssinica : drought-resistant 
bamboo, Prosopis cineraria, Simmondsia chinensis : jojoba, Solanum scabrum : African nightshade, Strychnos spinosa : monkey orange.

Tables and figures.

Table 1:Population in the sampled villages

\begin{tabular}{|c|c|c|c|c|c|c|}
\hline $\begin{array}{l}\text { Development } \\
\text { Area }\end{array}$ & $\begin{array}{l}\text { Population in } \\
\text { clustered villages }\end{array}$ & Male & Female & Total household & $\begin{array}{l}\text { Sampled } \\
\text { household }\end{array}$ & $\begin{array}{l}\text { Percentag } \\
\mathrm{e}\end{array}$ \\
\hline Balle & 11,635 & 63 & 58 & 2327 & 116 & 4.98 \\
\hline Bulanguwa & 11,034 & 54 & 56 & 2297 & 110 & 4.78 \\
\hline Dagona & 10,277 & 56 & 51 & 2055 & 102 & 4.96 \\
\hline Dapchi & 70,034 & 45 & 30 & 1406 & 80 & 5.68 \\
\hline Degeltura & 7,882 & 44 & 39 & 1576 & 78 & 4.94 \\
\hline Dumburi & 10,022 & 55 & 50 & 2004 & 100 & 4.99 \\
\hline Futchimiran & 4,209 & 21 & 26 & 841 & 52 & 6.18 \\
\hline Gumsa & 5,147 & 25 & 30 & 1029 & 61 & 5.92 \\
\hline Gwio kura & 16,377 & 86 & 82 & 3275 & 163 & 4.97 \\
\hline Gorgoram & 9,046 & 45 & 50 & 1809 & 100 & 5.52 \\
\hline Kanama & 6,889 & 34 & 37 & 1377 & 69 & 5.01 \\
\hline Karasuwa & 5,049 & 25 & 30 & 1009 & 60 & 5.94 \\
\hline Kaska & 13,747 & 68 & 70 & 2749 & 137 & 4.98 \\
\hline Machina & 13,081 & 65 & 70 & 2616 & 130 & 4.96 \\
\hline Muguram & 10,905 & 58 & 54 & 2181 & 119 & 5.46 \\
\hline Yunusari & 8,822 & 44 & 49 & 1764 & 95 & 5.39 \\
\hline Yusufari & 11,089 & 56 & 61 & 2218 & 111 & 5.00 \\
\hline Wachakal & 8,140 & 46 & 41 & 1628 & 96 & 5.90 \\
\hline Total & 170,385 & 895 & 884 & 34077 & 1779 & 5.22 \\
\hline
\end{tabular}

Source: National Population Commission (2001)

Table 2 Causes of Desertification

\begin{tabular}{|c|c|c|}
\hline Variables & Frequency & Percentage \\
\hline Expanding Desert & 250 & 14.3 \\
\hline Climatic Factors & 500 & 28.5 \\
\hline Population Pressure & 400 & 22.9 \\
\hline Livestock Pressure & 600 & 34.3 \\
\hline Total & 1750 & 100 \\
\hline
\end{tabular}

Source Field Data 2001

Table 3: Environmental change in the study area calculated from satellite Images

\begin{tabular}{|c|c|c|c|}
\hline Variables & $\begin{array}{l}\text { Landsat MSS of Gashua in } \\
1978(\mathrm{Ha})\end{array}$ & $\begin{array}{l}\text { Spot XS of Gashua } \\
\text { area 1995 (Ha) }\end{array}$ & $\begin{array}{l}\text { MODIS Image of Gashua } \\
\text { in 2002 (Ha) }\end{array}$ \\
\hline Sand dune coverage & $450,463.5$ & $500,307.5$ & $550,450.0$ \\
\hline Vegetation cover & $268,000.0$ & $260,000.0$ & $246,196.7$ \\
\hline Water body coverage & $188,596.9$ & $160,304.0$ & $140,296.0$ \\
\hline Bare ground & $69,800.0$ & $49,468.1$ & $26,349.4$ \\
\hline
\end{tabular}

Source: Author's Field Work (2001)

Table 4 Effects of Desertification

\begin{tabular}{|l|l|l|}
\hline Variables & Frequency & Percentage \\
\hline Reduction in Water Body & 220 & 12.6 \\
\hline Depletion of Vegetation Cover & 400 & 22.9 \\
\hline Shifting Sand Dunes & 230 & 13.1 \\
\hline Increasing Bare Ground & 300 & 14.1 \\
\hline Loss of Biodiversity & 600 & 34.3 \\
\hline Total & 1,750 & 100 \\
\hline
\end{tabular}

Source: Field Data 2001

Table 5 Control of Desertification.

\begin{tabular}{|l|l|l|}
\hline Variables & Frequency & Percentage \\
\hline Tree Planting & 400 & 22.8 \\
\hline Discourage tree felling & 350 & 20.0 \\
\hline Use of Kerozine Stove & 250 & 14.3 \\
\hline Irrigation & 250 & 14.3 \\
\hline Local Legislation & 250 & 14.3 \\
\hline Water Conservation & 250 & 14.3 \\
\hline Total & 1750 & 100 \\
\hline
\end{tabular}




\section{Plate 1 Classified LANDSAT MSS of Nashua Area 1978}

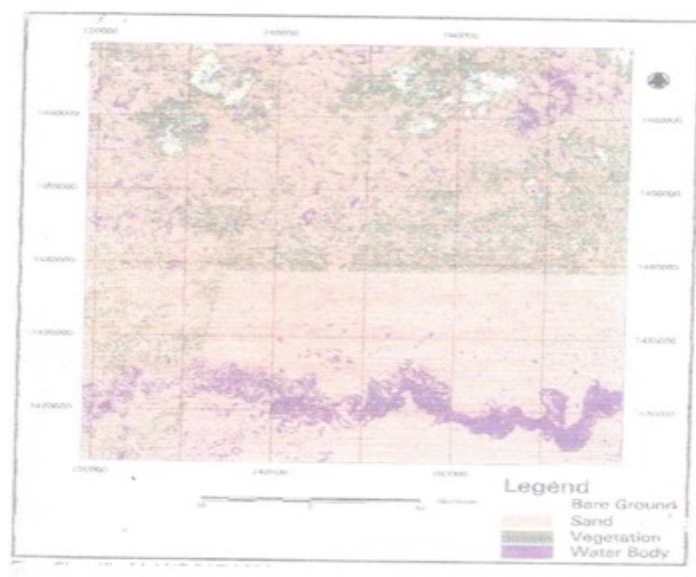

Plate 3.1 : Classified LANDSAT MSS Găshua Area (1978)

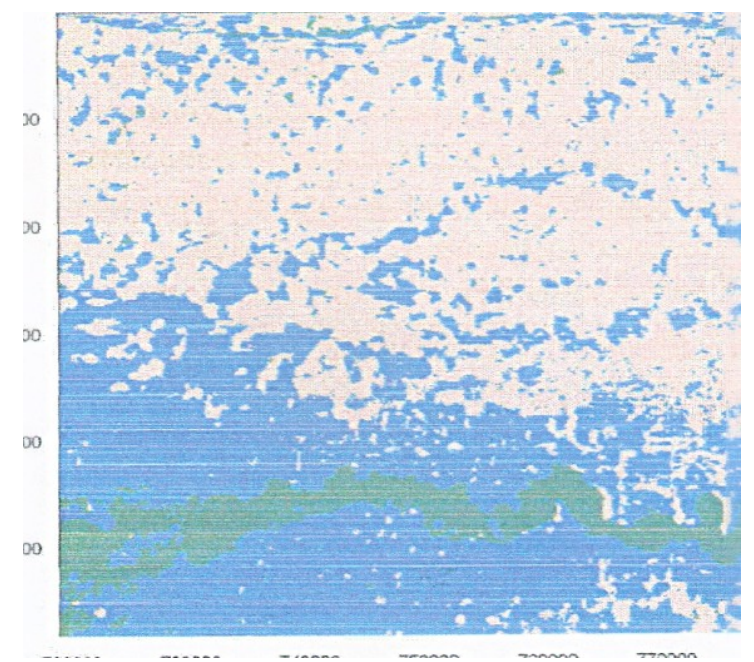

Plate. 2 Classified SPOT XS of Gashua Area 1995

Plate 3 Extensive bare Ground North-Eastern part of Tulo-Tulo Village, Yusufari

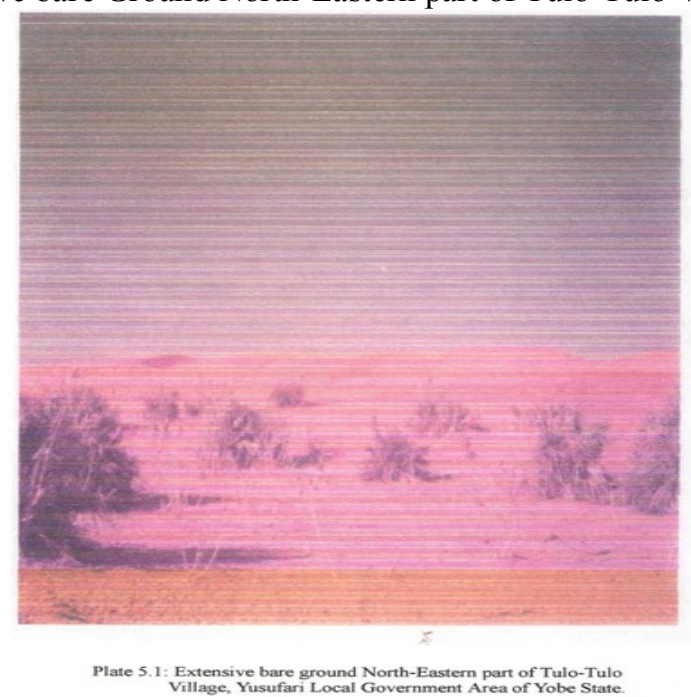




\section{References}

[1]. Julie, Kerr Casper (2007) Forests: More than Just Trees.

[2]. An Imprint of Infobase Publishing, New York.

[3]. Hjort Ornas, A. (1990). "Town-based Pastoralism on Eastern Africa," In Baker, J.

[4]. (ed.), Small Town Africa, Uppasala, the Scandinavia Institute of African Studies.

[5]. Mikesell, M. W. (1974). "Geography as a study of Environment: An Assessment of some old and new commitments", in Manner, I. R and Mikesell, M. W. (eds.),

[6]. Perspectives on Environment, Association of American Geographers Publication, Vol. 13, pp $1-23$

[7]. Mortimore, M. (1987). "Shifting Sands and Human Sorrow: Social Response to Drought and Desertification," Desertification Control Bulletin, No 14, pp $1-4$.

[8]. Olofin, E. A. (1989). "Human Responses to the Natural Environment in the Kano Region," and some of her Neighbors, ABU Press, pp $2-23$.

[9]. Silitshena, R. M. K. (1990). "Social Sciences Research on Drought in Botswana, Lesotho and Swaziland; a state of the Art Review," in International Development Research Centre (ed.), Drought in Africa, Ottawa, IDRC.

[10]. Uyanga, J. (2002). Indigenous Environmental Knowledge in North Eastern,

[11]. Nigeria,” Journal of Revitalization of Local Traditions, FRLHT, India,

[12]. Vol. 5, No 2, pp 5-10

[13]. Whitemore, M. (1990). "Land Resource Depletion” in Pearl M. C. ed .

[14]. Conservation for 21 st Century Oxford London. 